\title{
Childbearing Potential
}

National Cancer Institute

\section{Source}

National Cancer Institute. Childbearing Potential. NCI Thesaurus. Code C106508.

An indicator as to whether the female subject has the potential to become pregnant. 